\title{
Short Communication: Genetic diversity of lemon (Citrus spp.) from Ternate Island (Indonesia) based on morphological and molecular characters
}

\author{
ABDULRASYID TOLANGARA ${ }^{1, \vartheta}$, ALOYSIUS DURAN COREBIMA ${ }^{2}$, ABDU MAS'UD ${ }^{1, \bullet \bullet, ~ S U N D A R I ~}{ }^{1,3}$ \\ ${ }^{1}$ Departement Biology Education, Faculty of Teacher Training and Education, Universitas Khairun. Jl. Pertamina, Kampus II Unkhair, Gambesi, Ternate \\ 97728, North Maluku, Indonesia. `email: rasyid_17@unkhair.ac.id, ••email: abdumasud@unkhair.ac.id \\ ${ }^{2}$ Faculty of Mathematics and Natural Sciences, Universitas Negeri Malang. Jl. Semarang 5, Malang City 65145, East Java, Indonesia \\ ${ }^{3}$ Division of Biotechnology Laboratory, UPT LDT, Universitas Khairun. Jl. Pertamina, Kampus II Unkhair, Gambesi, Ternate 97728, North Maluku, \\ Indonesia
}

Manuscript received: 22 January 2020. Revision accepted: 10 April 2020.

\begin{abstract}
Tolangara A, Corebima AD, Mas'ud A, Sundari. 2020. Short Communication: Genetic diversity of lemon (Citrus spp.) from Ternate Island (Indonesia) based on morphological and molecular characters. Biodiversitas 21: 1908-1913. One effort to build the image of Indonesian lemon can be by utilizing local genetic resources of Citrus spp. One of the growth centra lemon regions in North Maluku is Ternate Island. In Ternate island, cui (C. macrocarpa) is dominantly cultivated besides that there are Suanggi $(C$. histryx), nipis (C. aurantiifolia), and lemon ( $C$ sinensis). The genetic diversity of these local lemons in North Maluku, especially in Ternate, has not been scientifically reported. Therefore, this study aimed to analyze the genetic diversity of local lemons found on the island of Ternate based on morphological character and RAPD molecular analyses. A total of 12 accessions of local lemons in Ternate island to studied for morphological and molecular characters. Observation of morphological and morphometric characters of the lemons on 117 characters of vegetative and generative organs in lemons. Observation of molecular characters using three primers, i.e.: OPA1, OPA 2, and OPA 3 in the RAPD technique. The morphological character and molecular character using UPGMA analysis showed similar results. Ternate Island has moderate diversity of lemon species (75\% based on morphological characters and $73 \%$ based on RAPD markers). Cluster analysis indicates that cui (C. macrocarpa) has the most distinctive autapomorphic character compared to the other local lemon varieties. Nipis (C.auratiifolia) and Suanggi (C. hystrix) shared $75 \%$ synapomorphic character similarity. This genetic diversity information provides a novel insight into the lemon commodity breeding programs which can be encouraged through the selection of superior local lemons based on morphological and molecular markers.
\end{abstract}

Keywords: Lemon, morphological, molecular, diversity, Ternate

\section{INTRODUCTION}

Lemon (Citrus spp.) is one of the genera of the Rutaceae family that has the highest economic value. The potential of local fruits including lemons has the potential to be developed as a source of diversification of food and nutrition, medicines and components of environmental improvement according to local conditions (Karsinah et al. 2002). Indonesia is known to have a variety of local and national superior citrus species spread throughout the archipelago from Sabang to Merauke, and has the potential to be developed and utilized to support food security, especially to meet the needs of the community's vitamins and minerals as the population continues to increase from year to year (Budiyati et al. 2016).

Ternate Island is known for its high diversity of tropical fruits. One of the examples of tropical fruits that are commonly bred on this island is lemon. Local lemons are widely spread on the island of Ternate. Lemon is a horticultural commodity of which demand has increased from year to year (Matakena 2017). Data obtained from the Department of Agriculture showed that national citrus production ranged between 17-25 tons/hectare from a potential of 25-40 tons/hectare ( Department of Agriculture
2007). As the population grows, the need for fresh cleansing agents also increases from year to year. According to Rezkianti et al. (2016) and Adelina et al. (2017), several steps that can be carried out to preserve tropical fruit germplasm in Indonesia include exploration (inventory and identification), introduction to increased genetic diversity, collection of observations, and evaluation of fruit production and development. These efforts play a very crucial role in providing diverse plant genetic resources for plant breeding, environmental conservation, and plant species diversity that ultimately serve to support sustainable food security (Budiyati et al. 2016; Murtando et al. 2016).

Agriculture in Indonesia targets the availability of new superior varieties that are productive and resistant to environmental stresses such as drought and pest attacks. To achieve this goal, having knowledge about genetic resource diversity is highly necessary. Access to genetic resources, both those obtained from exploration and from collection gardens can encourage the creation of new high-yielding varieties (Tobing 2013). Ternate Island is rich in tropical fruit diversity (Sundari et al. 2017). Various species of lemons such as cui (C. macrocarpa), nipis (C. aurantiifolia), Suanggi $(C$. hystrix $)$ and lemon $(C$. sinensis) are widely cultivated in Ternate. These local lemons differ in terms of 
fruit and leaf morphology and habitat characteristics. Data on the genetic diversity of lemons in Ternate has not been scientifically reported. Thus, information about this, is a new thing brought to the plant breeding and conservation efforts. Efforts to preserve and develop local plants are very important in providing a variety of plant genetic resources for plant breeding, environmental preservation, and increasing diversity of plant species to support sustainable food security (Solikin 2012). In addition, in Indonesia, there are about 400 kinds of edible fruit plants (Verheij and Coroe 1998) including the diversity of local lemon plants in North Maluku (Sundari et al. 2019). Several studies related to lemon breeding efforts have been any previous study of lemon using morphological and molecular characters, carried out in several countries including: Uzun et al. (2011) about genetic relationships among trifoliate oranges and their hybrid relatives based on ISSR markers; Pal et al. (2013) about genetic variability and relationship studies of mandarin (Citrus reticulata Blanco) using morphological and molecular markers; Khiavi et al. (2016) on the lime genetic diversity in three regions of Iran, using morphological and ISSR markers. This study aims to determine the genetic diversity of local lemons on Ternate Island based on morphology and molecular character of RAPD. This research is expected to contribute to the superior local lemon breeding model in North Maluku, Indonesia.

\section{MATERIALS AND METHODS}

\section{Study area}

This study was carried out from May to September 2019. Samples of this study were collected from eight villages in Ternate, North Maluku, Indonesia, includes four accessions namely cui, nipis, suanggi, and lemon. A purposive sampling method was employed to collect the samples of local lemon. The four local lemon varieties collected from Ternate Island are presented in Table 1.

\section{Procedure}

Morphological characters of the lemons were observed based on the Descriptors for Citrus (Bioversity International 1999). Observations were made on 117 morphological and Morphometric characters of vegetative and generative organs in lemons. Observation of molecular characters using the RAPD technique consisted of DNA isolation was carried out using a Presto TM Mini KIT (Geneaid) DNA kit. The amplification process uses MyTag Red Mix (Bioline). Primary amplification of OPA 1, OPA 2, and OPA3 with $30 \mathrm{~mL}$ PCR reaction mixture composition (MyTag Red Mix, Primary, ddH2O, and DNA templates). The PCR process was carried out under $94^{\circ} \mathrm{C}$ Pradenaturasi phases for 5 minutes at $94^{\circ} \mathrm{C}$, denaturation at $95^{\circ} \mathrm{C}$ for $5 \mathrm{~min}$, 45 cycles for $30 \mathrm{sec}$ annealing at $55^{\circ} \mathrm{C}$, and extension at $72^{\circ} \mathrm{C}$ for 90 seconds and posting extensions at $72^{\circ} \mathrm{C}$ for 7 minutes. DNA qualitative tests were performed using electrophoresis on $1.5 \%$ agarose gel with TBE $1 \mathrm{X}$ and photographed on GelDOC UV-transilluminator, while the quantitative test was performed using a spectronanodrop.
Table 1. Sampling locations in Ternate, North Maluku, Indonesia

\begin{tabular}{llc}
\hline $\begin{array}{c}\text { Location } \\
\text { (Villages) }\end{array}$ & \multicolumn{1}{c}{ Local name } & Number of trees \\
\hline Sango & Cui & 7 \\
& Nipis & 6 \\
& Suanggi & 6 \\
Kulaba & Lemon & 6 \\
& Cui & 7 \\
& Nipis & 7 \\
& Suanggi & 4 \\
Sulamadaha & Lemon & 7 \\
& Cui & 8 \\
& Nipis & 7 \\
Loto & Suanggi & 6 \\
& Lemon & 7 \\
Rua & Cui & 8 \\
& Nipis & 7 \\
& Cui & 7 \\
& Nipis & 7 \\
Sasa & Suanggi & 4 \\
& Lemon & 7 \\
Taduma & Cui & 6 \\
Kalumata & Suanggi & 4 \\
& Lemon & 8 \\
& Nipis & 7 \\
& Suanggi & 3 \\
& Cui & 6 \\
& Lemon & 5 \\
\hline
\end{tabular}

\section{Data analysis}

Moleculer data were obtained based on the presence and absent of DNA bands using primers. Score 1 shows the DNA bands that appear and score 0 for DNA bands that do not appear in each primary OPA (OPA 1-3). The data were analyzed using cluster analysis and the UPGMA (Unweight Pair Group Method with Arithmetic Mean) technique with the Multivariate Statistical Package (MVSP) program version 3.22 (Kovach 2007).

\section{RESULTS AND DISCUSSION}

\section{Morphological characters}

There are 117 variations of morphological characters (phenotypes) found in the four local lemon such as cui $(C$. macrocarpa), nipis ( $C$. aurantiifolia), Suanggi ( $C$. hystrix) and lemon ( $C$. sinensis). These variations are identified in the vegetative organs (leaf and stem characters) and generative organs (characters of flowers, fruits, and seeds) of these lemons. Analysis of species similarity using the MVSP ver 3.22 software has produced a dendrogram consisting of two lemon groups with a similarity value of $56 \%$. The first main cluster with a similarity value of $56 \%$ consists of one of lemon, namely Cui lime. The second group with a similarity value of $68 \%$ is comprised of one cluster group with a similarity value of $75 \%$ is divided into two sub-clusters, consist Lemon and namely Nipis and Suanggi (The similarity values for the three lemon groups are presented in Table 2 (genetic distance matrices) and Figure 2 (Dendrogram UPGMA). The results of the cluster 
analysis with dendrogram are presented in Figure 1. The description of distinguished morphological characters of the lemons is presented in Figure 2. Diversity analysis of Ternate lemons was analyzed based on DNA band visualization (Figure 3). The similarity matrix of lemon DNA is shown in Table 5.

Based on the dendrogram above, we know that autapomorphic characters (unique characters in one taxon) owned by the first group (Cui lime) and the second group (lemon) are: two stem characters (stem height and stem surface), three-leaf characters (leaf shape, length, and width), three fruit characters (skin shape, texture, and color), and two seed characters (seed shape and size). Synapomorphic characters (shared characters) that belong to the third group (Suanggilime and Nipis lime) consist of 10 characters that include two stem characters, three leaf characters, three fruit characters, and two seed characters.
The description of the autapomorphic and synapomorphic characters of the lemon species is shown in Table 3.

\section{Molecular characters}

Data on the DNA band appearance in the four local lemon species are presented in Table 4. The total number of DNA bands found was 26 bands with 20 polymorphic bands). The average percentage of polymorphism was $73.21 \%$ (Table 4). Matrix similarity analysis is based on the appearance of DNA bands (DNA profile) (Figure 3).

Table 2. Genetic distance matrices of Ternate lemon morphometric characters

\begin{tabular}{lllll}
\hline & Nipis & \multicolumn{1}{c}{ Lemon } & Suanggi & Cui \\
\hline Nipis & 1 & & & \\
Lemon & 0,746 & 1 & & \\
Suanggi & 0,748 & 0,676 & 1 & \\
Cui & 0,556 & 0,595 & 0,561 & 1 \\
\hline
\end{tabular}

\section{UPGMA}

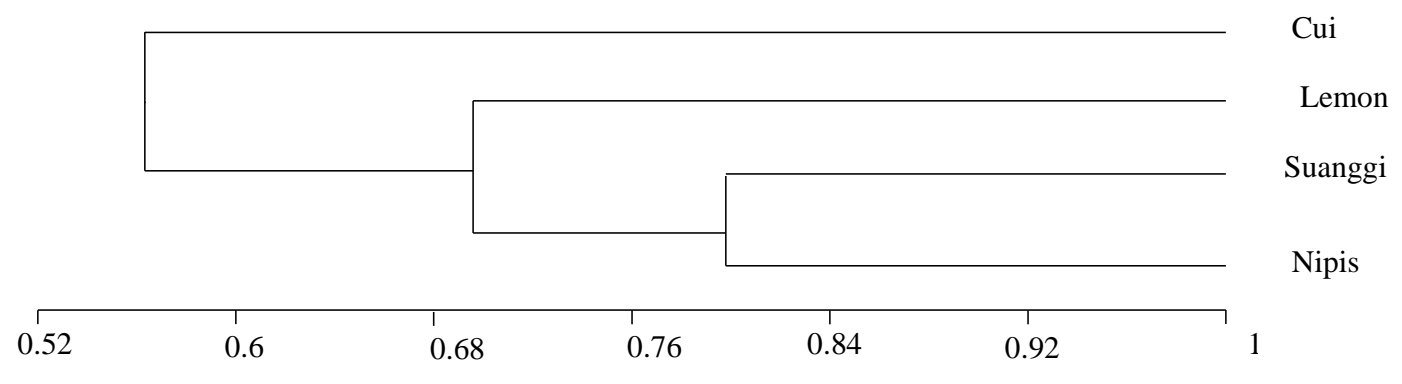

Simple matching coefficient

Figure 1. Dendrogram of Ternate lemon morphometric character

Table 3. The Autopomorphic and synapomorphic characters of the four lemon species found in Ternate Island

\begin{tabular}{|c|c|c|c|}
\hline Cluster & Analysis & OTU & Character state \\
\hline 1 & Autopomorphic & Cui & $\begin{array}{l}\text { Medium stem height, barbed stem surface, orbicular-shaped leaf, small fruit } \\
\text { size, smooth texture in dark green color fruit, ovoid-shaped seed }\end{array}$ \\
\hline 2 & Autopomorphic & Lemon & $\begin{array}{l}\text { High stem height, barbed stem surface, abovate ovalic shaped leaf, medium-to- } \\
\text { large fruit size, smooth texture in green color fruit, ovoid seed }\end{array}$ \\
\hline 3 & Sinapomorphic & Suanggi and Nipis & $\begin{array}{l}\text { High stem height, smooth stem surface, elliptical-shaped leaf, medium fruit } \\
\text { size, rough texture fruit, green color fruit, fusiform seed }\end{array}$ \\
\hline
\end{tabular}

Table 4. Primer sequences with the number of scorable amplified and polymorphic

\begin{tabular}{llcccc}
\hline Primer & Seq 5 to 3 & $\begin{array}{c}\text { Number of } \\
\text { amplified }\end{array}$ & $\begin{array}{c}\text { Number of } \\
\text { polymorphic bands }\end{array}$ & $\begin{array}{c}\text { Number of Monomorphic } \\
\text { bands }\end{array}$ & $\begin{array}{c}\text { Polymorphic bands } \\
(\%)\end{array}$ \\
\hline OPA 1 & AGT CAG CCA C & 11 & 11 & 00 & 100 \\
OPA 2 & AAT CGG GCT G & 07 & 04 & 03 & 57.14 \\
OPA 3 & CAG CAC CCA C & 08 & 05 & 03 & 62.5 \\
Total & & 26 & 20 & 6 & 73.21 \\
\hline
\end{tabular}




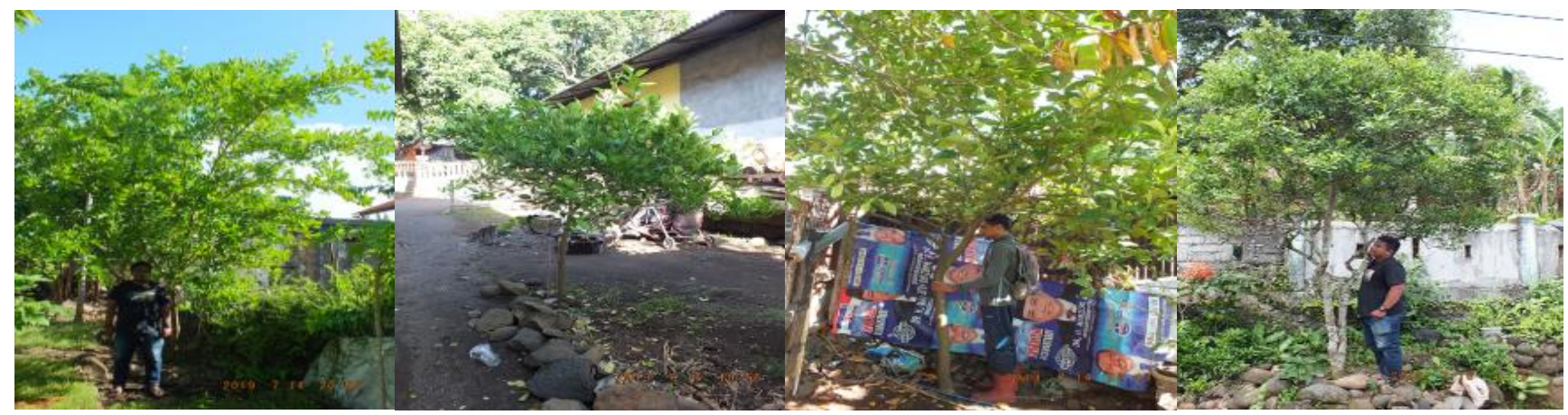

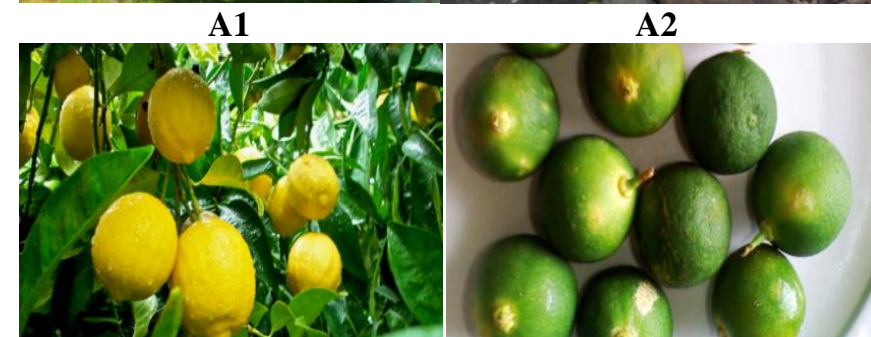

B1

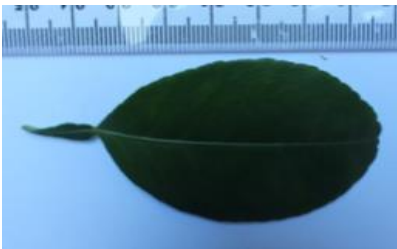

C1
B2

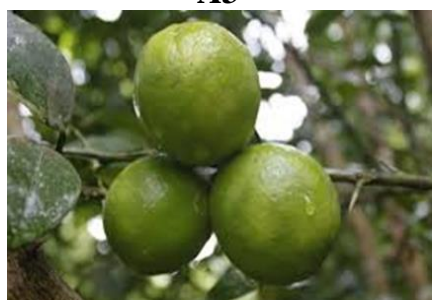

B3

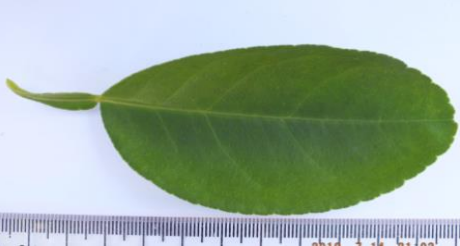

C2

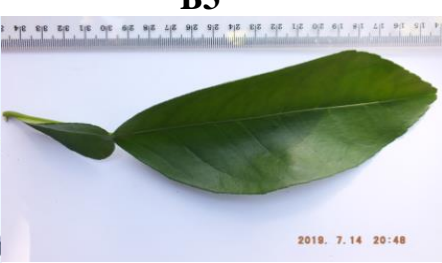

C3
A4

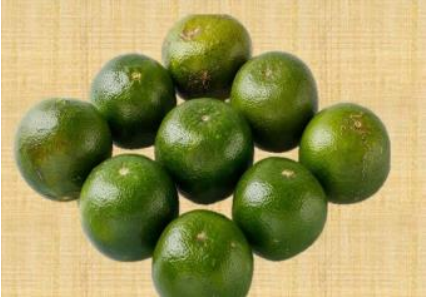

B4

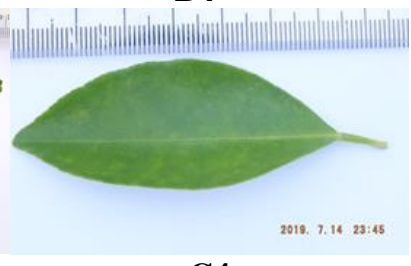

C4

Figure 2. The distinguished characters of Ternate lemon morphology. A. Tree, B. Fruits, C. Leaf. 1. Cui, 2. Suanggi, 3. Nipis tree, 4. Lemon

The highest similarity matrix value $(0.783)$ is found in Suanggi and Nipis (Table 5), suggesting that the two species share many identical features. Dendrogram generated based on the average value of similarity matrices of the Ternate lemon DNA is shown in Figure 4.

UPGMA cluster analysis based RAPD molecular characters shows two main clusters with a similarity value of $54 \%$. The first main cluster with a similarity value of $54 \%$ consists of Cui, the second group with a similarity value of $70 \%$ is comprised of lemon, and subcluster divided into Nipis and Suanggi.

\section{Discussion}

Ternate Island has moderate diversity of lemon species (75\% based on morphological characters and $73 \%$ based on RAPD markers according to our results. Lower similarity values indicate higher diversity this is in line with Wijayanto et al. (2013) and Rachma et al. (2017) stated that the smaller the coefficient of similarity (close to 0 ), the more distant the relationship; conversely, the greater the coefficient of similarity (close to 1). the closed the relationship. From the results of this study and referring to Nei (1987), the value of local lemon genetic diversity on Ternate Island was classified as moderate. This result can be used as a reference in local Lemon breeding activities. Based on the results of this study, it can be understood that the genetic diversity of lemons in Ternate is moderate than the intraspecies level of Durio spp from Ternate island (Sundari et al. 2017).

Table 5. Similarity matrices of the ternate lemon species

\begin{tabular}{lcccc}
\hline & Nipis & Lemon & Suanggi & Cui \\
\hline Nipis & 1 & & & \\
Lemon & 0.706 & 1 & & \\
Suanggi & 0.783 & 0.696 & 1 & \\
Cui & 0.554 & 0.595 & 0.545 & 1 \\
\hline
\end{tabular}

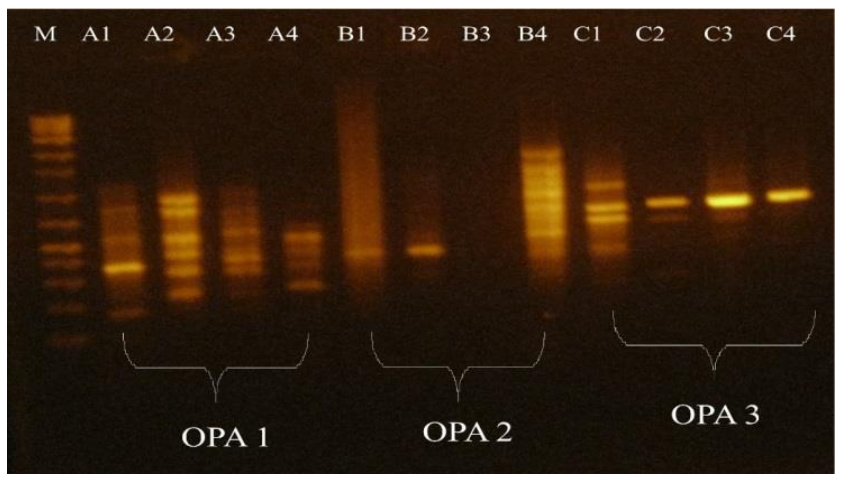

Figure 3. Visualization of DNA bands based on RAPD primers 
UPGMA

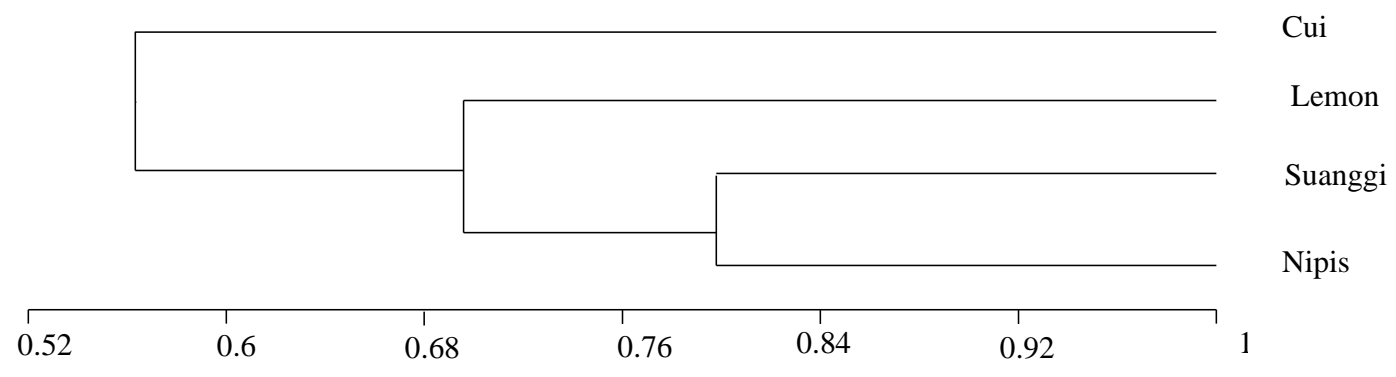

Simple matching coefficient

Figure 4. Dendrogram of RAPD analysis

According to (Calinski and Harabasz 1974) and Sturn et al. (2002), grouping or cluster analysis can be used to classify individuals or objects into groups with different characteristics. Individuals or objects that belong to the same group will have relatively homogeneous properties this is in line with finding of Daryono et al. (2019). The data of this study have revealed that local lemon of Ternate is enough diverse. The close relationship between Suanggi and Nipis is presented in a dendrogram. Cluster analysis performed in this study used euclidean distance that varies from 0.0 to 0.1 to express the similarity level of traits among lemon species. Genetic distance was used in this study because each of the species characters has a comparable scale (Figures 3-4).

Very high genetic diversity of citrus can be demonstrated by the high number of species and hybrid taxonomic units (Cottin, 2002). Polyembryonies, hybridization, mutations, and phenotypic diversity are one of the causes of the difficulty of identification and classification of citrus. There is a large collection of citrus germplasm originating from local varieties with names according to their home regions, or the same cultivars with different names (Machado et al. 1996). Exploration results from the species of citrus and their wild relatives indicate that Indonesia is rich in sources of germplasm. Citrus plants spread almost all over Indonesia. In some areas, there are many types of citrus with unknown origins, as if they were native to the area and known as local cultivars (Sugiyarto and Supriyanto 1992).

Lemon leaves vary greatly so that they can provide information about characters that are systematically manifest (John 1965; Stuessy 1990; Williams 2010; Aydin et al. 2013). Leaf morphological characters are normally used to determine diversity of plant species (Murtando et al. 2016). Leaf color can vary depending on the condition of the plant's habitat, water and food supplies, and irradiation. In general, upper and lower surfaces of a leaf have different colors. The upper leaf surface usually looks greener, shinier, and more slippery than the lower leaf surface (Tjitrosoepomo 2009; Murtando et al. 2016). Ternate citrus leaf shape is mostly elliptical or orbicular with acute (pointed) leaf tip, serrated leaf edges, smooth leaf surface, oblique leaf shape, and green color. The color of the leaf flush petiole also varies from light green to green.

According to Rezkianti et al. (2016); Adelina et al. (2017), environment is a determinant factor in the diversity of a plant population in an area. The environmental factor consists of: altitude, rainfall, temperature, and humidity are supporting factors of plant growth. This means that differences in one of the environmental factors will affect the characters (both morphological and physiological) of similar plant populations (Ismail et al. 2019). For an example of the morphology of the color of the leaves and the structure of the rind of a Nipis.

The results of molecular analysis in this study are in line with morphological analysis, this shows that the morphological characters used in identification are quite representative to study genetic diversity of local lemon in Ternate Island. According to Sunaryono (1982) several steps that must be carried out in the context of efforts to preserve germplasm fruit plants in Indonesia, including citrus plants, among others; exploration (identification and identification), introduction to increase genetic diversity, and collection of observations and evaluations in order to increase production and development. This research is an exploration of genetic diversity through an inventory and identification of local lemons on the island of Ternate. This genetic diversity data will be used as a basis for local lemon crossing techniques in order to improve quality. Lemon cui is the most distant lemon, it can be used as a crossed parent.

In conclusion, this study has unveiled a similar result between the morphological analysis and RAPD molecular 
analysis conducted to four local lemon species found on Ternate Island has moderate diversity of lemon species (75\% based on morphological characters and $73 \%$ based on RAPD markers). Cluster analysis shows that Cui has the most distinctive autapomorphic characters compared to the other local lemons. Nipis and Suanggi have a moderate similarity value $(75 \%)$ and shared similar synapomorphic characters.

\section{ACKNOWLEDGEMENTS}

The authors would like to thank LPPM Khairun University for providing a postgraduate research grant in 2019. Thanks to Ismat Ishak, and Sulfikar Harun for their assistance in sample collection.

\section{REFERENCES}

Adelina SO, Adelina E, Hasriyanty H. 2017. Morphological identification and anatomy of local oranges (Citrus sp.) in Doda Village and Lempe Village, Lore Tengah District, Poso Regency. Agroekoteknologi 5 (1): 58-65. [Indonesian].

Aydin O, Coşkunçelebi K, Gultepe M, Guzel ME. 2013. A contribution to taxonomy of Centaurea including Psephellus (Asteraceae) based on anatomical and molecular data. Turkish J Bot 37 (3): 419-427. DOI $10.3906 /$ bot-1204-25

Bioversity International. 1999. Descriptor for Citrus IPGRI. Roma, Italy.

Budiyati E, Nirmala FD. 2016. Utilization of exploration results of Nusantara orange germplasm. Jurnal Agroteknologi 9 (1): 58-66. [Indonesian]

Calinski T, Harabasz J. 1974. A dendrite method for cluster analysis Commun Stat Theor Meth 3 (1): 1-27.

Cottin R. 2002. Citrus of The World, A Citrus Directory Version 2. SRA INRA-CIRAD, France.

Daryono BS, Subiastuti AS, Fatmadanni ASD. 2019. Phenotypic and genetic stability of new Indonesian melon cultivar (Cucumis melo L.'Melonia') based on ISSR markers. Biodiversitas 20 (4): 1069 1075. DOI: $10.13057 /$ biodiv/d200419

Department of Agriculture. 2007. Prospects and Direction of Developmen of Agricultural Commodities: Review of Land Resources Aspects. Agricultural Research and Development Agency. Agro Innovation, Jakarta. [Indonesia]

Ismail AY, Kusmana C, Sudiana E, Widodo P. 2019. Short Communication: Population and stand structure of Cinnamomum sintoc in the low land forest of Mount Ciremai National Park, West Java, Indonesia. Biodiversitas 20 (4): 1042-1047. DOI 10.13057/biodiv/d200415

John CS. 1965. Comparative Plant Anatomy: A Quide to Taxonomic and Evolutionary Applications of Anatomical Data in Angiosperm. Holt Renehart \& Winston, New York.

Karsinah S, Setyobudi L, Aswidinnoor H. 2002. Genetic diversity of orange germplasm based on analysis, RAPD marker. J Agric Biotech 7 (1): 8-16.

Khiavi SJ, Hamidoghli Y, Golein B, Sabouri A. 2016. Assessment of lime genetic diversity in three regions of Iran using morphological and ISSR markers. Agric Commun 4 (3): 18-29.
Kovach WL. 2007. Multivariate Statistical Package (MVSP) Plus Version 3.22 User's Manual. Kovach Computing Services.

Machado MA, Filho HDC, Targon MLPN, Pompeu J. 1996. Genetic relationship of Mediterannean mandarins (Citrus deliciosa Tenore) using RAPD markers. Euphytica 92: 321-326.

Matakena S. 2017. Sweet orange commodity (Citrus sinensis L) agribusiness in Wadio Village, West Nabire District, Nabire Regency. Jurnal Pertanian Dan Peternakan 2 (1): 35-47. [Indonesian].

Murtando H, Sahiri N, Madauna I. 2016. Identification of morphological and anatomical characteristics of local citrus plants (Citrus sp.) in Karya Agung and Karya Abadi Village, Taopa District, Parigi Moutong District. E-j. Agrotekbis 4 (6): 642-649. [Indonesia].

Nei M. 1987. Molecular Evolutionary Genetics. Columbia University Press, New York.

Pal D, Malik SK, Kumar S, Choudhary R, Sharma KC, Chaudhury R. 2013. Genetic variability and relationship studies of mandarin (Citrus reticulata Blanco) using morphological and molecular markers. Agric Res 2 (3): 236-245. DOI: $10.1007 / \mathrm{s} 40003-013-0072-8$

Rachma RA, Hendrian H, Azrianingsih R. 2017. The analysis of Pandanus relationship of Purwodadi Botanical Garden collections based on morphological character and molecular marker (trnL and $\operatorname{trn} \mathrm{L}-\mathrm{F})$. Res J Life Sci 4 (2): 129-140. [Indonesia].

Rezkianti V, Maemunah M, Lakani I. 2016. Morphological identification and anatomy of local oranges (Citrus sp.) in Hangira Village and Baleura Village, Lore Tengah District, Poso Regency. Jurnal Online Agroekoteknologi 4 (4): 412-418. [Indonesian].

Solikin. 2012. Exploration of the local fruit of Madura, East Java. Proceedings of the National Seminar on Perhorti in collaboration with UPN "Veteran" East Java 2012. Building Synergy Stake Holders to Increase Competitiveness of Horticultural Products. Published April 2013

Stuessy TF. 1990. Plant Taxonomy, The Systematic Evaluation of Comparative Data. Columbia University Press, New York.

Sturn A, Quackenbush J, Trajanoski Z. 2002. Genesis: Cluster analysis of microarray data. Bioinformatics 18 (1): 207-208.

Sugiyarto M, Supriyanto A. 1992. Commencement of citrus plants. Proceedings of the East Java Regional Commissariat Plant Breeding Symposium. Matured Food Crops Research Institute.

Sunaryono H. 1982. Preservation of Fruits. Minutes of the Horticultural Workshop. Research and Development Center, Bogor.

Sundari, Arumingtyas EL, Hakim L, Azrianingsi R, Wahyudi D. 2017. Genetic variability of local durian (Durio zibethinus Murr.) in Ternate island based on RAPD markers. Plant Cell Biotech Mol Biol 18 (1\&2): 68-75

Sundari, Nurhasanah, Mas'ud A, Amin M, Arumingtyas EL, Azrianingsih R. 2019. Update phylogenetic information of the local varieties of cloves (Syzygium aromaticum) from North Maluku, Indonesia based on ITS sequences data. Biodiversitas 20 (6): 1510-1515. DOI: 10.13057/biodiv/d200604

Tjitrosoepomo G. 2009. Fundamentals of Plant Taxonomy (General Taxonomy). Gadjah Mada University Press, Yogyakarta.

Tobing, Bayu, Siregar. 2013. Identification of morphological character in the compilation of description of citrus (Citrus nobilis) in some Karo Districts. Jurnal Online Agroekoteknologi 2 (1): 72-85. [Indonesia]

Uzun A, Gulsen O, Seday U, Yesiloglu T, Aka-Kacar Y, Tuzcu O. 2011. Investigation of genetic relationships among trifoliata oranges and their hybrid relatives based on ISSR markers. Romanian Biotechnol Lett 16 (4): 6431.

Wijayanto T, Dirvamena B, Ente L. 2013. Relationship the kinship of the Kepok banana accession (Musa paradisiaca forma typica) in the Regency Muna based on morphological characters and RAPD markers. J Agroteknos 3 (3): 163-166.

Williams DM. 2010. Plant Taxonomy: The Systematic Evaluation of Comparative Data 2nd ed. Columbia University Press, New York. 